\title{
The Manifestations of Care and Happiness for the New-born in Ancient Egypt and its Assimilation to the Inherited Folklore
}

\section{Dr. Nour Galal Abdel Hamid Dr. Amany Abdel Rehim}

\section{Abstract:}

This research deals with the manifestations for the newborn in ancient Egypt - even there are no details account- it traces the remains of such customs and rituals in our inherited folklore ${ }^{1}$. This paper focuses on the social aspect of ancient Egyptians and the beginning of life that the newborn symbolizes in particular. The goal of the study is to shed light on such manifestations. Furthermore, it studies the nature of the related celebrations. The research comments on the rituals of the mother and her baby and links between the custom of "Seboua"سئبوع (literally the seventh day in Arabic) celebration in the Egyptian inherited folklore and its relation with customs of their predecessors. The multiple sources of the study stress primarily on the most famous newborn Horus, the religious and archaeological remains as well as the medical texts, which partly deal with the treatments for women in and after childbirth, and for pregnancy.

\section{Key words:}

newborn; placenta; child; soboua; mammisi; seven; birth; sieve; folklore.

- Associate Professor, Faculty of Arts Archaeology Department, Ain Shams Universit - Lecturer, Faculty of Arts Tour Guidance Department, Ain Shams University

${ }^{1}$ Folklore is traditional art, literature, knowledge, and practices that are passed on in large part through oral communication; American Folklore Society, 2016.

$$
\text { 1999. - 199. }
$$

Ethnographic studies of any sort relatively scarce in Egypt except some ancient efforts such as:

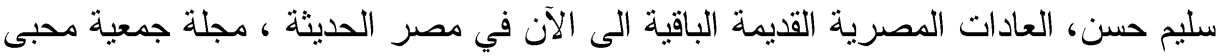

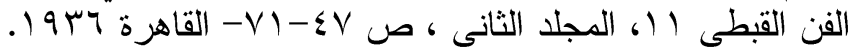




\section{1-Introduction}

Rituals and ceremonies flourish in every culture, and have done so throughout history. The two most ritual-inspiring events perhaps are birth and death. Children in ancient Egypt were considered a great blessing. ${ }^{2}$ Many children were wanted and that families were often large, a woman often gave birth to twelve or more children, few of whom survived into adulthood. ${ }^{3}$ Fertility was a central aspect of an ancient Egyptian woman's life. ${ }^{4}$ The ancient Egyptians had a suitable idea of pregnancy. Gods are responsible for the procreation and protection of the embryo, the Great hymn of Aten is said that: "the god 'Itn brings in being the seed $m 3 y$ in the women, makes water into men (ir $m w$ m rmt $)$ and feeds the son in his mother's womb" ${ }^{5}$, woman in pregnancy, considering her little more than a vessel holding the baby while it grows. The symbolic role of the Egyptian queen as the "hand" ( $d r t$, "hand", is grammatically feminine) of the creator. ${ }^{6}$ At the same level, they were aware of the importance of male creativity in fertility ${ }^{7}$, most did acknowledge that a baby acquired qualities from both its mother and father. The Kahun, Berlin 3.038 and Carlsberg papyri contain an extraordinary series of tests for

${ }^{2}$ Child-birth practices in Egypt are well known and have been the subject of study by E. Feucht, Kind, LÄ III, 430; id., Das Kind im Alten Ägypten (New York 1995) and "Birth", The Oxford Encyclopedia of Ancient Egypt (ed. D. Redford) (Oxford 1999) 192-193; A. Marshall, Étre un enfant en Egypte ancienne, 1980; id., Maternite et petite enfance en Egypte ancienne, 2015.

${ }^{3}$ C. Goucher, C. Le Guin, and L. Walton, "Ordering the World:Family and Household," in In the Balance: Themes in Global History (Boston: McGraw-Hill, 1998), pp. 301-5. E. Scott's volume provided a useful assessment of the presence of children in the archaeological record, The Archaeology of Infancy and Infant Death Oxford (1999).

${ }^{4}$ The female figurines found at both Deir el Medina and el - Amarna, misleadingly known as concubines, Pinch denoted that the term fertility figurine is more appropriate; G. Pinch, Childbirth and Female Figurines at Deir el-Medina and el- Amarna. Orientalia Nova Series, vol. 52, No. 3 (1983), p. 405.

5 M. Sandman, Texts from the time of Akhenaten (Bruxelles (1938), pp. 94:10.

${ }^{6}$ M. Rikala, A Rebirth for the Pharaoh, p. $1 \wedge \varepsilon$

7 A. M. Roth, Ancient Egyptian Beliefs about conception and fertility in: A. Rautman,(ed.) Reading the body, University of Pennsylvania Press, p. 191. 
fertility, accordingly the foremost duty of a married woman was to get as many children as possible (the death rate was high).

Perhaps keeping a dead infant near its mother in her home earth promoting fertility, helping her to give birth to another child embodying the spirit of the deceased. Roth suggests that ancient Egyptians considered birth and rebirth after death as closely related events, both of which were regarded as dangerous transitions. Given their importance, we should not be surprised by the variety and complications of the rituals, symbols, and implements used to ensure their successful completion that $p s \check{s}-k f$ ${ }^{8}$ with determinative ${ }^{\top}$ and the $n t r t j$ are offered in the Pyramid Texts ritual after the spells that simulator the king's passage through the birth canal and before he begins to nurse. ${ }^{9}$ These implements employed in opening of the mouth ${ }^{10}$ was used in ordinary life to cut a newborn infant's umbilical cord, preparing it to life. ${ }^{11}$ Roth strongly argued for an interpretation of this rite as referring to the activities taking place at child birth. Remains from these rituals can be observed in Folklore in (Tahnik) or wept the baby's mouth. ${ }^{12}$

\section{2- Child birth:}

Giving birth to a male child is a favorite and delightful. In Palermo stone, the announcement of a male child is an important event for the king, the $2^{\text {nd }}$ row part of the reign of a king, most

${ }^{8} \mathrm{~Wb}, \mathrm{I}, 555.3$

${ }^{9} p s \check{s} \mathrm{kf}$ most likely role in birth would have been to cut the umbilical cord; Roth, op.cit, 123.

${ }^{10}$ The Opening of the Mouth ceremony carried out on the mummy on the day of burial to restore to the deceased all his earthly faculties; R. Grieshammer, Mundöffnungs ritual, LÄ IV, 223-24; Jequier, MIFAO 47 (1921), p. 323; E. Otto, Das Ägyptische Mundoffnungsritual, Wiesbaden (1960)

${ }^{11}$ Roth, Ann Macy, "The $p s \check{s}-k f$ and the "Opening of the Mouth' Ceremony: A Ritual of Birth and Rebirth," JEA 78 (1992), pp. 113-147.

${ }^{12}$ M. Roth , Fingers, Stars, and the 'Opening of the Mouth': the Nature and Function of the ntrwj-blades, JEA 79 (1993), pp. 57-79). Such a concept fits perfectly the idea of rebirth of the dead in a statue. 


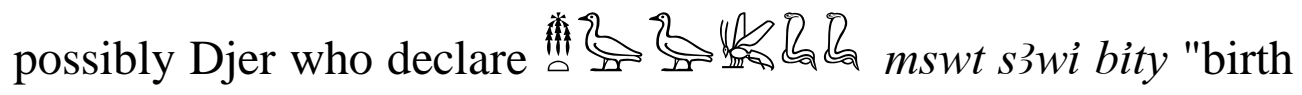
of two royal children". Teeter showed a letter written on a pottery jar stand in eight vertical columns from unidentified man to his deceased father, asking him to assist in the birth of a son to his wife Seny "I beg a second healthy male child for your daughter". ${ }^{13}$ but this does not mean that they hated female's birth. There are also a few masculine names that clearly refer to the mother of a newborn son: ihy.n.s"She has a calf," (where the word for "calf" alludes to the son of Hathor). And iw.f-n-mwt.f "He belongs to his mother". ${ }^{14}$

Death of infants and even fetuses were casually treated. Great care was taken to ensure they received the proper burial rites according to the beliefs of time. Two mummified fetuses, placed in individual coffins, were found in King Tutankhamen's tomb no. $317 \mathrm{a}(2)$, no. $317 \mathrm{~b}$ (2), the care taken in the preparation of this burial clearly demonstrates the value placed on life even in the first weeks of its inception. ${ }^{15}$

B2 is the determinative of a pregnant woman can be seen in (bk3) to be pregnant and (jwr) conceive. In the Chaotic elements (hhw, nnw, thmmw and $k k w$ ). ${ }^{16}$ Category of figure vase is made up of stone vessels depicting naked women who are clearly pregnant it has been suggested that these jars held a substance used to ensure the health of the unborn child, ${ }^{17}$ other pregnant female

\footnotetext{
${ }^{13}$ E. Teeter, Ancient Egypt, Chicago, 2003, p. 36; A similar case a letter from first or second century (Papyrus Schmidt) "It is Esrmpe... Who is complaining about Hor (her husband) ... he does not have sex with me... My lord Osiris.... I am childless. I have no protector son" F. Piety, Religious practice and Pietyin Oxford Handbook of Roman Egypt, Oxford (2012), p. 324.

${ }^{14}$ G. Fischer, Egyptian women on the old kingdom, The Metropolitan Museum of Art, New York (2000), p. 35.

${ }^{15}$ Foetus burials in pottery jars were found within habitation at Maadi Neolithic and Chalcolithic communities, perhaps as a magical means of warding off future miscarriages and stillbirths; W. Hayes, Most Ancient Egypt, Chicago (1965), pp. 112, 130.

${ }^{16}$ W. Barta, GM 127 (1992), pp. 8-9.

${ }^{17}$ C. Roehrig, R. Dreyfus, C. Keller (eds.), Hatshepsut: From Queen to Pharaoh, p. 234; British Museum, London, EA 54694; 24652; Musée du Louvre N 969.
} 
figurines to be left at shrines or in tombs to assure the pregnancy of a member of the domestic sphere . The embryonic or fetal self occurs as light, fire or brightness. ${ }^{18}$ Sometimes headlessness, can be representation of formlessness and the embryo, a symbol of rebirth, ${ }^{19}$ among the object of the treasures of Tutankhamun was ornamental jar cover depicting a nest and several eggs, one of the eggs has been broken by the gosling, who chirrups out his joy to be alive and flaps his wings the young prince is portrait as the sun of the solar goose. ${ }^{20}$

The hieroglyph of the woman giving birth is encoded in the Gardiner's sign list as B3 and B4, can be used as a logogram for msy "birth" but is more often used as a determinative following the phonetic spelling of " $m s$ " as F31 (the 3 fox pelts)

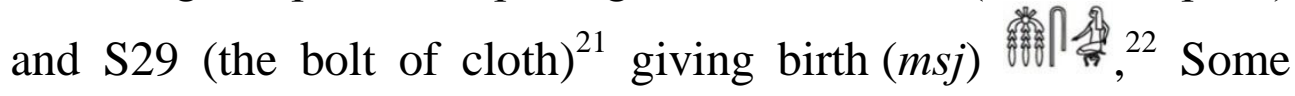
names even reflect

circumstances immediately prior to or during parturition: ii $\mathrm{mw}$ "The fluid comes" or "May fluid come;" hwi.f r.i "He beats against me;" phrr.s"She turns about;" ḩbs "One who is covered., 23

The most detailed account on childbirth is a single Papyrus Westcar (Berlin 3033) (around 1600 BC), which comprises five stories. ${ }^{24}$ The fifth story is a prophecy of the birth of three kings

${ }^{18}$ F. Renggli, The Sunrise As The Birth Of a Baby: The Prenatal Key to Egyptian Mythology, Journal of Prenatal and Perinatal Psychology and Health, 16(3), (Spring 2002)

19 B. Stricker, De Geboorte van Horus, vol. 5, Leiden (1989), Fig. 78, pp. 672-85. Women usually prayed to goddesses like Hathor and Isis to grant them a child.

${ }^{20}$ C. Noblecourt, Gifts from the Pharaohs, Singapore (2007), p. 75.

${ }^{21} \mathrm{~Wb}$, II, 139. 1-1406.

${ }^{22}$ W. Kaiser, Zu den mswt die älteren Bilddar stellungen und Bedeutung von $r p w t$, MDAIK 39 (1983), pp.261-293; other names: imty (LGG I, 299), hwn (LGG I, 54), št3 $m$ ht , (LGG 1 28), hy rnpy (LGG I, 99), nwn (LGG 1. 80), id, nhnn (LGG I ,252).

${ }^{23}$ G. Fischer, op.cit, p.35.

${ }^{24}$ Berlin, Ägyptisches Museum und Papyrussammlung, inv.no. p. 3033; M. Lichtheim, Ancient Egyptian Literature, Volume I: The Old and Middle Kingdoms. Berkeley: University of California Press (2006), pp. 220-222; A. Blackmann, Aylward M. The Story 
fathered by Re (col. 9.21:10.13), ${ }^{25}$ There were also five deities; Isis (placed herself before her), Nephtys (behind her), Heqet (hastened the birth), ${ }^{26}$ Meskhenet $^{27}$ (prophesy that the three newborns will become king of Egypt) and Khnum, all disguised as female musicians, arriving to assist her They used a portable birthing-stool, with a hole in it for the baby to pass through. The story showed who the father was worried

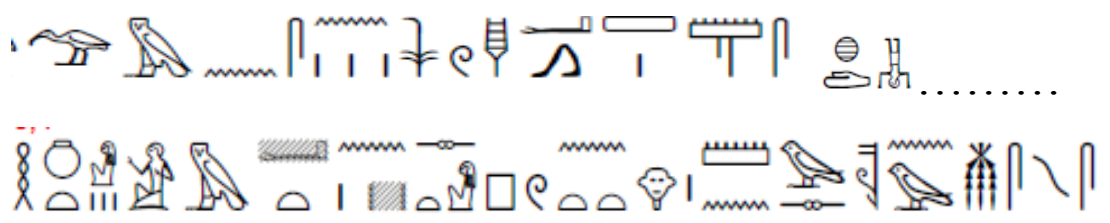

gm.n.sn sw ${ }^{\top}{ }^{\top}(. w) d 3 i w$ shd(.w)......

hnwwt.i men st pw ntt ḥr mn.s ksh ms.s

"they found him standing with kilt upside down....". ${ }^{28}$ Westcar $10-2$

of King Kheops and the magicians. Reading: JV Books, 1988. Translation: Simpson, William Kelly. King Cheops and the magicians In: K. Simpson (ed.), The literature of ancient Egypt. An anthology of stories, instructions, stelae, autobiographies and poetry. New Haven: Yale University Press; 2003, pp. 21-22.

${ }^{25}$ K. Simpson, King Cheops and the Magicians. In: Simpson, William Kelly (ed.), The literature of ancient Egypt. An anthology of stories, instructions, stelae, autobiographies and poetry. New Haven: Yale University Press (2003), pp. 21-22; In the tale just related triplets are born, a relatively rare matter, only three pairs are at present known. One of them the brothers Niankhkhnum and Khnumhotep, of the Fifth Dynasty, the second pair are the architects of Amon Temple under Amenhotep III, Suti and Hor. A third pair may be the two sisters represented on a Twelfth Dynasty stela; M. Rosalind, J. Janssen, Growing up and Getting old in Ancient Egypt, London (2007), pp. 9-10.

26 "Heqet" was considered to play part in assisting at the birth of the sun god from the primordial water; see Heqet: Altenmüller, Synkretismus, p. 159; L. Kákosy, LÄ II, 334336; LÄ II, 1123-1124; Bonnet, RÄR G, 198-199.

${ }^{27}$ M.-Th. Derchain-Urtel, 'Mesechenet', LÄ IV, 107.

${ }^{28}$ K. Ritner, Household Religion in ancient Egypt, in Household and Family Religion in Antiquity edited by Saul Olyan, J. Bodel, Blackwell Publishing (2008), pp. 171-196.

His disordered kilt is probably an indication that he ia a distraught, but it may allude to an act of sympathetic magic, in which undoing knots was supposed to ease giving birth; R. Parkinson, The Tale of Sinuhe and other Ancient Egyptian Poems, 1940-1640 BC, Oxford University Press (1997), p. 125, note. 50. 
"My Ladies, Look, there is a woman who is suffering for her labour is difficult" Westcar 10-4

After giving birth, Reddjedet paid the midwife-deities in corn and 'cleansed herself in a purification of fourteen days. ${ }^{29}$

The New Kingdom prototypes emphasized the divine birth of the ruling pharaoh. ${ }^{30}$ The birth cycle was first worked out among the reliefs of Hatshepsut's mortuary temple at Deir el Bahri are two extensive narrative series. ${ }^{31}$ In royal ideology, as was especially uttered after the reign of Hatshepsut, the king had a legitimate claim to the throne because he had been conceived by a god. ${ }^{32}$ Although some variant accounts provide different details on the day and place of birth. ${ }^{33}$ An idea that the pr-mswt 'birth houses' derived from Old Kingdom prototypes in the funerary temples was recently raised by $\mathrm{H}$. Altenmüller. ${ }^{34}$ Although he admitted that their identification is not obvious, he suggested antechamber square but it appears now that the entrance rooms fit much better

${ }^{29}$ M. Lichtheim, Ancient Egyptian Literature, I. The Old and Middle Kingdoms, Berkeley (1973), p. 220.

${ }^{30}$ F. Daumas, "Geburtshaus” LÄ II (1977), cols. 462-475.

${ }^{31}$ Helene J. Kantor, Narration in Egyptian Art, AJA, Vol. 61, No. 1 (Jan., 1957), pp. 4454; E. Naville, The Eleventh Dynasty Temple at Deir el-Bahri Vol. I (EEF Memoir 28, London (1907) pls. xiv, A, D, F, H; xv. 32 Naville, The Temple at Deir el-Bahri, Vol. III (EEF Memoir 16, London I896-1897), pls. LVI-LXIV; C. Campbell, The miraculous Birth of King Amen-hotep III and other Egyptian Studies (Edinburgh and London 1912), pp. 149, figs. I-13, fig. 15; Gayet, Le temple de Louxor, fasc. I: Constructions d'Aminophis III (Memoires de la mission archeologique francaise au Caire, Vol. 15, Cairo 1894), pls. LXIILXVII.

${ }^{32}$ H. Brunner, Die Geburt des Gottkönigs. Studien zur Überlieferung eines altägyptischen Mythos, ÄA 10, 1964, p. 194-203; L. Bell, "The New Kingdom «Divine» Temple: The Example of Luxor", in B.A. Shafer (ed.), Temples of Ancient Egypt (1997), pp. 137-139

${ }^{33} \mathrm{Ph}$. Derchain, Le Papyrus Salt 825 (B.M. 10051): Rituel pour la conservation de la vie en Égypte. Brussels: Palais des Académies (1965), p. 31; A. Gutbub, Textes fondamentaux de la théologie de Kom Ombo. Bibliothèque d'étude 47. Cairo: Institut français d'archéologie orientale (1973), p. 13; Herbin, François-René, Les premières pages du Papyrus Salt 825, BIFAO 88 (1988), p. 99.

${ }^{34}$ H. Altenmüller, Geburtsschrein und Geburtshaus, in: Studies Simpson, Boston (1996), pp.27-37). 
this concept. ${ }^{35}$ They used the words mshnt "place of birth" ${ }^{36}$ and $\underline{d b t y}$, two blocks to identify the place of birth.$^{37}$ There are documents affirming that a woman also gave birth to a child in her own home, but other evidence suggests that most deliveries, at least in the New Kingdom took place in special buildings that might be called birth-arbors bk3t nt swt (a rush of read) ${ }^{38}$ (Figure 2). In Ptolemaic times, upper-class women may have given birth in the birth-houses attached to temple's Mamisi. ${ }^{39}$

Woman gave birth squatting on two large bricks, the so called Birth bricks,${ }^{40}$ with the handful of older women who had enough experience in delivering babies, personified as the goddess Meskhenet $^{41}\left(\text { in }^{\complement} t\right)^{42}$ (in Arabic "Daia" دايه). Magical bricks are quite different than mud bricks, although many have similar rectangular shapes. The materials used also differ, as magical

35 On this issue and the Simpson's mrt-chapels see also Baud, Michel. Famille royale et pouvoir sous l'Ancien Empire égyptien 1. Bibliothèque d' Étude 126/1. Cairo: Institut Français d'Archéolgie Orientale (1999), pp. 345-346.

${ }^{36}$ Pap. Med. London \{8\} 3.7; H. Grapow, Grundriss V, 436.

${ }^{37}$ Pap. Chester Beaty VII, rt.5, 7-8 and 6, I.

${ }^{38}$ There is an ostracon from Deir el Medina suggesting, that eight menstruating women left the village together to go to 'the place of women'; A. G. McDowell, Village Life in Ancient Egypt: Laundry Lists and Love Songs, Oxford University Press (2002), p.36.

39 Mamisi a term for a birth house inside a temple complex where the birth of the divine child was celebrated, derived from Coptic $\overline{\mathbf{M}} \boldsymbol{\lambda}$ place $\overline{\mathbf{N}}$ of and $\overline{\mathbf{M}} \mathbf{\Theta \Theta}$ "The place of giving birth; Daumas, Les mamisis de temples égyptiens, (1958), p. 15; F. Daumas, Les mammisis des temples egyptiens. Paris: Les Belles Lettres; (1958), p. 15-27; Kockelmann, Holger. Mammisi (Birth House) In: Wendrich, Willeke, ed. UCLA Encyclopedia of Egyptology, Los Angeles, 2011. Available online: http://escholarship.org/uc/item/8xj4k0ww [accessed 30 May 2016].

${ }^{40}$ Birth bricks help women into a physiological upright posture during labor and birth. They can also provide balance and support to laboring women, allows the pelvic floor muscles to stretch more easily and allow the women to use her thigh muscles along with her abdominal muscles and uterus in a way that does not fight gravity; also used by different societies, for discussion on the Medieval age; see J. Towler, J. Bramell, Midwives in History and Society, New Hampshire (1986), p. 82; H. A. Winkler, Agyptische Volkskunde (Stuttgart, 1936), 188.

${ }^{41}$ R. Wilkinson, The complete gods and goddesses of ancient Egypt. London: Thames \& Hudson (2003), pp. 152-153.

${ }^{42}$ The word $i n^{\prime} t$ in Old Kingdom is quite unknown in such a context, but it certainly designates an occupation of some importance; G. Fischer, op.cit, p. 27. 
bricks are made from finely sifted clay as opposed to the mud and straw used in preparing mud bricks. ${ }^{43}$ There is an ancient song in which birth bricks are confirmed in it. ${ }^{44}$ Moreover in Mesopotamia the same idea existed. Deity present and the one responsible for bringing in the birthing stool. ${ }^{45}$ This use is attested in several ethnographic parallels from relatively modern times. This tradition clearly survived through the Coptic Period ${ }^{46}$ into Islamic times. ${ }^{47}$

In the Osiris myth, it was Heqet who breathed life into the new body Horus at birth, as she was the goddess of the last moments of birth. As the birth of Horus became more closely associated with the resurrection of Osiris, Heqet's role became one more closely associated with resurrection. ${ }^{48}$ In the New Kingdom, Bes occurs in reliefs and paintings related to child birth. At Deir elMédina Bruyére found figures of women dancing or nursing a child, and marsh scenes alluding to the birth of Horus. ${ }^{49}$

\section{3- Famous Birth of the Gods:}

Imagine procreation among the gods is the same way as the human procreation, So logically the stages of human growth, like

\footnotetext{
43 Silverman, Magical Bricks of Hunuro, p. 731; Dbt may refer to a block of various materials, including cloth and it seems likely that the two blocks were generally made of something more comfortable than dried mud. For this matter see Gay Robins, Women in Ancient Egypt, London (1993), p. 83.

${ }^{44}$ A. Roth, JEA 78, 142 (fig. 10). The text includes the exhortations 'Behold the mystery of birth!' and 'Oh, pull!'.

${ }^{45}$ Cf. M. Stol, Birth in Babylonia and the Bible. Its Mediterranean Setting (Cuneiform Monographs 14; Groningen (2000), 119-122.

${ }^{46}$ A fragmentary Coptic magical text, upon bricks which Mary was elevated when she gave birth to Jesus. W. E. Crum,' Bricks as Birth-Stool', JEA2 8 (1942), p. 69.

47 A. M. Soheir, Childbirth in an Egyptian village In: M. Artschwager Kay (ed.), Anthropology of Human Birth, Philadelphia (1981).147-174.

${ }^{48}$ Heqet amulets gaining the phrase "I am the resurrection" in the Christian era along with cross and lamb symbolism; A. Louise, The Frog on Lamps from Kranis, Medieval and Middle Eastern Studies. Brill (1972), p. 357.

${ }^{49}$ B. Bruyére, Un Fragment de fresque de Deir el Médinah, BIFAO 22(1923), 121-33; id., Deir el Médinah, 59-60, figs. 145, 157, 182, pls. IX-X; J. Vandier d' Abadie, une Fresque civile de Deir el Médinah, RDE 3 (1938), pp.27-35
} 
the gods, The sun god Ra, reflects the evolution of man: in the morning, he is the newly born child, at noon he reaches the peak of his might and power and in the evening he symbolizes old age, decline and finally death before he is reborn the next morning as the symbol of rebirth ${ }^{50}$. The sunrise is understood to represent the birth of the baby, emerging from lotus $51 \check{s} s p^{52}$ is used in reference to both the setting of the sun in the west, and the birth of the sun in the east. The feminine character of the sky abstracted in the goddess Nut, who gives birth to the sun every day (Pyr. 16886)

Birth played a very important role in creation myths. Sometimes it appeared in the shape of an egg and other times in that of a mother giving birth to children.53 The most obvious expression of this is the belief that the sky goddess Nut swallowed and protected the sun god on his nightly journey through the underworld. In ancient Egypt the newborn infant was seen as an embodiment of god Horus. ${ }^{54}$ A Hymn to Osiris from Dynasty 18 (stela Louvre C 286) narrates Isis actions in the form of two scenes: (1) Isis' search and her care for the body; and (2) the conception, birth, and childhood of Horus. The birth of Hours has been extensively studied by Stricker. ${ }^{55}$ The terminology of the

\footnotetext{
50 A. Piankoff, La Création du Disque Solaire (Creation and the Sun Disk). Kairo: Institut Français d' Archeologie Orientale (1953).

${ }^{51}$ For the association of the lotus with the birth of the sun, compare the lotus painted at the bottom of the belly of an image of a pregnant woman, in: L. Keirmer, The Decoration of the New Kingdom vase, JNES 8 (1949), p. 3, pl. 6; H. schlogl, Der sonnengott auf der Blüte, eine ágyptische kosmogonie des Neuen Reiches, Geneva (1977).

${ }^{52}$ Wb. IV 531, 10; J. Assman Liturgische Lieder an den Sonnengott. Berlin: Hessling (1969), pp. 202-3.

${ }^{53}$ In ancient Egyptian Language there is no special term for myth the common word for tale or story is $s \underline{d} d t$ "that which is told": V. Dijk, Myth and Mythmaking in Ancient Egypt, in Religious and science, (1698).

${ }^{54}$ E. Scott, The Archaeology of Infancy and Infant Death, Oxford, 1999, p. 2; Van Dijk, The Birth of Horus According to the Ebers Papyrus, JEOL 24 (1979-80), pp. 4-11.

${ }^{55}$ B. Stricker, De geboorte von Horus (5 vols; Leiden: Ex Oriente Lux, 1963-1980; see esp. vol II (1968), p. 131. For the case study of the application of myth in medical or magical texts see V. Dijak, The Birth of Horus According to Ebers Pap. Jaarbericht Ex Oriente Lux 26 (1979-1980).
} 
birth of Horus resembles that of Shu's birth (CT II, 68b; 71b; 77d-78a; 79c [96]. After the baby is born, the mother or a friend might announce that the infant is Horus or some other deity. As a child, Horus was known as Harpokrates ${ }^{56}$ a young nude boy with a finger to the lips, well known and described in the Pyr. 378, \& 63c, 664a, "the infant Horus", and was portrayed as a baby being suckled by Isis. Representations of Isis with Horus are among the most common of all bronze statuettes from the Late Period. ${ }^{57}$

Humans are usually born out of their mother's womb, but gods actually have lots of creativity in that. Other miracles such as figure in the temple of Hibis is the pregnant Ptah, who has just given birth to the pair of Shu and Tefnut. Seth broke through his mother's side and leapt forth. ${ }^{58}$

4- After Birth: The placenta $\ominus h^{59}$ is also called the after-birth. The placenta probably held a special significance, The Unwritten Folklore or named the Mashima "El wald el Tany" which means "another or second child", as the woman tries to tore the spirit of the child into her body again so that she may conceive once more; She also tries to capture the spirit of the other child. ${ }^{60}$ It is

56 G. Roeder, Ägyptische Bronzefiguren (Berlin 1956), § 313; G. Robins, Women in Ancient Egypt (London 1993), p. 23. The Greek word "Kourotrophos" comes from the Greek "Kouros", meaning child and trophos rearer, nurse to refer to the "female and child"; L. Budin, Images of woman and child from the Bronz Age, New York, Cambridge University Press (2014), p. 29.

57 The representations of a divine child - Horus on the laps of Isis did not occur before the New Kingdom. However, as remarked by Goedicke, Re-used Blocks, p.146 n. 383.

58 Te Velde, Seth, God of Confusion: A study of his role in Egyptian mythology and religion. Leiden: E.J. Brill (1967), p. 27.

${ }^{59}$ Ptolemaic examples of the placenta see: E. Devaud, Etudes de Lexicographie égyptienne et copte, Kemi 2 (1929), pp. 11-12.

${ }^{60}$ Frankfort, Kingship, p. 365, n. 55; W. Blackman, The Fellahin of Upper Egypt, London (1968), p. 63. This book republished 2000 by the American University Press in Cairo, very important hence the author observed social, economic, and religious life of the Egyptian fellahin in the early part of the twentieth century.

Some ancient cultures view the placenta as a twin which deceived any evil, or the midwifery was burn it on the fire, some said one could tell how many more children the woman would have by counting the pops it made, or buried in a garden with a shrub 
an organ formed specific for pregnancy and is essential for normal fetal growth and development. ${ }^{61}$ It is the interface between the mother and the baby and stabilizer for the growing baby. The ancient Egyptian recognized its importance, the placenta was believed to be a source of power and magic and its term is $m w t-r m \underline{t}$ which literally means «mother of humankind». ${ }^{62}$ The dried placenta appears as an ingredient in magical spells, ${ }^{63}$ if a woman died while giving birth to a child, her afterbirth might have been placed into her body cavity during the mummification process. ${ }^{64}$ An Egyptian pharaoh was preceded in procession by his actual placenta, fixed to the end of the pole. ${ }^{65}$ In our popular traditions buried under the edge of the house, ${ }^{66}$ or was thrown into the Nile to ensure that the child survived. ${ }^{67}$ Various

planted over, see more rituals from different cultures see; E. Hartland's introduction to the article on Birth in Hastings Encyclopedia of Religion and Ethics II, placenta, p. 639.

${ }^{61}$ It is the only organ the human body can grow when needed and removed when its function is over. The body can grow a new one when needed again.

${ }^{62} \mathrm{~S}$. Topfer, The physical activity of parturition in ancient Egypt: textual and epigraphically sources Dynamis (2014), 34 (2): 328.

${ }^{63}$ D. Montserrat, Sex \& Society in Graeco-Roman (1996), p. 30; mentions also the $h r w w d$ 3 a demotic term which may mean "the day of being apart" may be post-natal seclusion.; ibid.

${ }^{64}$ M. Mekota, G. Grupe, M. R. Zimmerman, and M. Vermehren, First Identification of an Ancient Egyptian Mummified Human Placenta International Journal of Osteoarchaeology Int. J. Osteoarchaeol, (2005), p. 59.

${ }^{65}$ M. Blackman, The Pharaohs Placenta and the Moon-God Khonsm, JEA 3 (1916), pp. 235-291.

${ }^{66}$ In Asna (Live when a women give birth the placenta was buried inside the clay pot and buried under the house entrance.

${ }^{67}$ Cf. Many cultures (throughout history and even today) add much significance on honoring the placenta by burying it. In New Zealand, the Maori traditionally bury the placenta on tribal land which helps the child to establish a personal and spiritual connection to the land. The Navajo will bury the placenta to ensure that the child will always return home. Cambodians believe that a child will be safe as long as they stay near to where their placenta was buried; Buckley, Dr Sarah, "Birth Preparation: Placenta Rituals and Folklore" sourced from mothering.com on 2nd June 2012. The people of the Pacific Islands bury the placenta in the garden to ensure that the child will grow into a good gardener; E. Cornelia,"Placenta: The gift of life", Mother baby press, 2011. In Indonesia, a family may bury a paintbrush with the placenta (to bring artistic talent), or a pen to encourage the child to be a writer, or a pinch of rice to bring prosperity to the child's life. In Bali, the placenta is believed to be the physical body of the child's guardian angel and is therefore treated with utmost respect; L. Robin "Placenta, The Forgotten Chakra", Half Angel Press, Bali, Indonesia (2010). 
occurrences of the word $h b 3$ means "navel" or "umbilical cord", 68 are included in CT. $317,{ }^{69}$ and in chapter 17 of the Book of the Dead. $^{70}$

\section{5-Newborn:}

The most comman general names of the newborn were: mst, ${ }^{71}$ ?

$\theta$ the word hy is well-known with the meaning "child" or "infant baby", 72 \& dissertation reads this word as a newborn. ${ }^{74}$ The newborn baby was described such as: prt $m \underline{h} t^{75}$ "going forth from the body", "the one who emerged from the (mother's) belly"; $w b \underline{h} t^{76}$ Opening the body; wttsw $\underline{d}$.f having himself begot (Allen, spell 185Es1); some descriptions related to sacred ideas such as: Osiris first-born $s m s w$, first-born of first-born $(s m s s m s)$...CT 168 \& S50, spell 69a, p2; . The verb "3" to spit- to ejaculate also used for throwing out of the child during birth-giving CT IV, $181, \mathrm{j}$ and VII, 181, h; pri $m m s w$ which describes the rise of the sun god from primeval water; When a baby was born it was said by the Egyptians to $w^{\ulcorner} r t^{77}$, flee, the same word used to describe

${ }^{68}$ A. Blackman, Some Remarks on an Emblem upon the head of an ancient Egyptian Birthgoddess, JEA 3(1916), pp. 203-206; B. Bell, ZÄS 65 (1930), pp. 1-63; Gardiner, ZÄS 66 (1931), p. 71.

${ }^{69}$ R. Faukner, The Ancient Egyptian Coffin Texts I, London (1973), p. 214.

${ }^{70}$ R. Faukner, The Ancient Egyptian Book of the Dead, London (1985), p. 45

${ }^{71} \mathrm{~Wb}$ II, 140, 16-141, 13.

Baines noted that there is an inherent connection between taking form and coming into being; J. Bains, "Mswt "Manifestation?" In Hommages a François Daumas, vol.1, Montpellier (1986), pp. 43-50, n.43,

${ }^{72} \mathrm{~Wb}$ III 217, 3-9.

${ }^{73} \mathrm{~Wb}$ III, 52; The sun god called hy in the morning and $n h h$ old man in the evening; $W b$. III, 217, 5; the only representation of a king as a naked infant dating from the Old Kingdom is the alabaster figure of Pepi II in Brooklin and in all instances of relief representations before the New Kingdom the king is shown as a grown man with his royal insignia.

${ }^{74}$ Hayes, structure, p. 129 , notes 89.

${ }^{75} \mathrm{~Wb}$ III, 356; Urk'Ih:811:16.

${ }^{76} \mathrm{~Wb}$ III, 357.

${ }^{77} \mathrm{~Wb}$ I, 286, 16 and 18. 
the rush of the waters of inundation ${ }^{78}$. There were special spells represent the birth and the cleaning of the newborn (Pyr. 28, 29c, Pyr. 29a-b). ${ }^{79}$ It was normal for Egyptian women to breast-feed their children for a full three years. Child and mother, suckling or nursing in the statues and images are the symbol of the sacred motherhood $^{80}$ (Figure 3), $\mathrm{c}$ 5 kneeling, breastfeeding woman (the word for suckle: rnn). Statuette of a woman suckling her children dates back to the Old Kingdom. ${ }^{81}$

The suckling motif established the deceased king firmly within the realm of deities. Several of the Utterances suggest that the divine milk consumed by the deceased would promote his return to life. In Utterance 470, \& 913 the goddess Nekhbet tells the king: "O my son, take my breast and suck it, that you may live and be little again". El-Moshahara (an Arabic word for month ${ }^{82}$ ), it is an Egyptian rite still practice especially in Upper Egypt to protect the milk for the child. Midwifes made a special amulet, mothers stepped over it three times then put it into a water which use again during the mother's bath.

The birth of Osiris has been represented in the scenes and inscriptions of one of the rooms of the roof in Dandara Temple; Osiris was represented in the fetal position inside his mother's womb like an embryo in the womb of his mother as he prepared to go out into the world.$^{83}$ It is one of the most famous scenes

${ }_{79}^{78}$ A. Roth, JEA 78, p.118.

${ }^{79}$ G. Grignon, Sante et hygiene de L' enfant dans l' Egypte ancienne (2001).

${ }^{80}$ CG 34125; Vandier, Manuel II, 508 fig. 302; British Museum, EA 809; Berlin Ägyptisches Museum 14441; 17600; 12764; 14078; Brooklin Museum of Art, 43.137komata; 51.224; 51.21 .

${ }^{81}$ Berlin 14479.

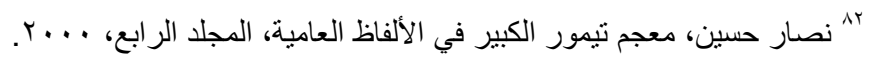

${ }^{83}$ For the body of Osiris as a womb of the newborn sun, see: J. Zandee, The Birth- Giving Creator God in Ancient Egypt, in A.B. Lioyd (ed.) Studies in Phraonic Religion and Society in Honour of J. G. Griffiths (1992), p. 177. 
that had to be represented in the festivals celebrating the reincarnation of Osiris ${ }^{84}$ and the everlasting eternity. ${ }^{85}$

The use of artifacts and images relating to childbirth were similar with mortuary context such as: The magical bricks had the same function of the birth bricks. Even the world of the gods as the same of human, being the texts frequently speaks about the loner rebirth (CT III, 1606, 207): The goddesses are addressed in the following terms; Oh you two, who give birth at night, come and give to me; Oh you two who become pregnant during the day, may you give birth to me, even the one who is in egg". The dead also identified themselves with the sun god Re, however, who went through a never-ending daily cycle of death at sunset and resurrection at sunrise. The Egyptians believed that after the sun god had died and entered the underworld beyond the horizon in the west, he temporarily merged with Osiris. Thus Re-Osiris was imbued with new life and was able to be reborn in the morning as Horus, the son of Osiris. This reborn sun god is therefore called Re-Horakhty.

After the goddesses cut the navel cord, washed the child and laid it on a pillow of cloth, also swaddled with a baby cloth (In

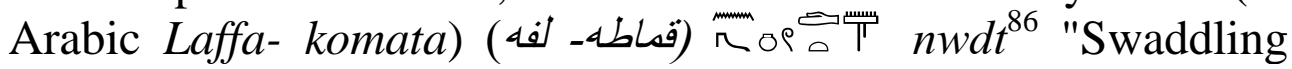
bands" to protect from evil spirits, the swaddling disguised the baby as mummified, to fool the evil spirits out of a baby. The wrapping also symbolized the god Ptah, a god of protection and healing. ${ }^{87}$ Luke's gospel records (Luke 2-7) that Mary wrapped her newborn baby son in bands of cloth. This was normal practice. The strips of cloth (swaddling) held the limbs of the baby firmly, though not tightly, giving the baby a sense of

\footnotetext{
${ }^{84}$ On Osiris festivals: Emile Chassinat IFAO, 1966 and 1968; Perpillou, Thomas F. Fétés D' Égypte ptolémaique et Romaine D' Aprés La Documentation Papyrologique Grecque Studia Hellenistica 31, 1993. This book offers a complete survey of all Festivals, official and private in Greco- Roman Egypt.

${ }^{85}$ For Osiris as the womb of the new born sun see: J. Zandee, op.cit.

${ }^{86}$ Ebers Pap. Rubric 273, column 49

${ }^{87}$ E. Staehelin, Binding und Entbindung, ZÄS 96 (1970), pp. 125-39.
} 
security, and limiting it as it had been confined in the womb bands, were believed to promote strong, straight bones as the baby grew.

Bath and symbolic rule of water: Egyptian religion, like most others, used water for many purificatory purposes derived from Heliopolitan worship of Re. ${ }^{88}$ Bath week of the child must be by the exotic waters of the River Nile. ${ }^{89}$ For soap Egyptians used natron sntr $b d$, hsmn, $s w^{c} b u$ (derived from $(s) w a b$ meaning to clean). Seboua in some Nubian villages revolves around the river with the work of a small boat looks like a sun boat and placed in the direction of the sunrise, ${ }^{90} \mathrm{Cf}$. in Christianity as soon as a baby was born, it was washed by the midwife. She used items: olive oil, salt, warm water, and sometimes wine. Each ingredient had a purpose: the salt and wine had antiseptic quality, the water melted and diluted them, the oil was smoothing to the baby's skin immediately after this cleansing, and the baby was wrapped in coarsely woven linen strips.

The water symbolizes the new life in Coptic church, there is no new life without water (Eizekiel $\varepsilon: 17)$. In Baptism ritual in the Orthodox Church, the newborn was placed in holy water to expel the devil and make him the son of Christ (Figure 5). He then rubs holy oil, prepared by the Pope, on the infant's body, forehead, on his chest for healing the soul and the body, over his hands saying your hands are my doing, and on his feet, to walk in the way of the god. Christian name the rite of baptism "enlightened". Christian is called who obtain the rite of Baptism the enlightened. ${ }^{91}$ Boys circumcision, was practiced at home in

${ }^{88}$ Blackman JEA, 1918, 117-24; Gardiner 36, (1950), pp. 3-12.

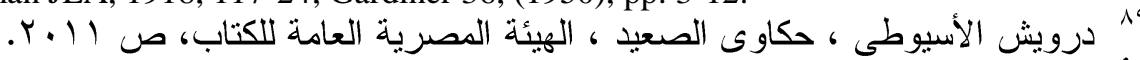

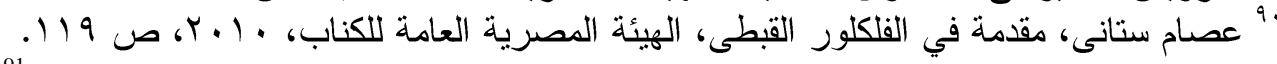
${ }^{91}$ Infant baptism for Catholics, Eastern is a practice of baptizing infants or young children 
Egypt from the earliest times, and from there it was adopted by the Israelites and by the Phoenicians. ${ }^{92}$

Egyptian magic literature includes a separate category of spells designed for the protection of helpless infants. Many of the spells designed to protect the Newborn identify it with Horus the child. Several of these are contained in one papyrus now in Berlin: A spell for a knot "Are you warm in the nest? Are you hot in the bushes? Is not your mother with you..." ${ }^{13}$ Waraksa interprets the ceramic female figurines from the Mut Precinct, Karnak, as antvenom and healing spells preserved in Papyrus Turin 54003 rt. 13-14 and P. Leiden I 348. ${ }^{94}$

Several spells hung about the neck (amulets) of the children, applied at the feet, given in hand, tied on their heads, placed under head, anointed with oil. The purpose of the amulets (In Arabic: herz (حزَز) - Taawiza (تعويذه), Tamima (تميمة) is clearly important to confer success in child- bearing. Many children died of infection and disease so amulets for the newborn were often tied to the child's body for protection. The hippopotamus amulet were preferable, as an animal, it was widely diffused in the Egyptian Nile Valley and Delta during the (late) pre-dynastic period its massive body and violent temper are the main aspects of this animal's ambivalent symbolism: its size, aquatic habitat and protective behavior with puppies originate the association of (female). ${ }^{95}$

\footnotetext{
92 See further, Maurice Stracmans "A propos d'un texte relatif a la circoncision egyptienne (1re periode intermediaire)," Melanges Isidore Levy (1955), pp. 631-39.

${ }^{93}$ M. Raven, Egyptian Magic, The Ques of Thoth's, The American University in Cairo Press (2012), p. 90.

${ }^{94}$ E. Waraska, Female Figurines (Pharaonic Period) bearing an appeal for a child, Ucla Encyclopedia of Egyptology, p. 3; id., Female Figurines from the Mut Percinct, Johns Hopkins University (2007).

${ }^{95}$ F. Raffaele, Animal Rows and Ceremonial Processions in Late Pre-dynastic Egypt, 252; D. Osborn, and J. Osbornová, The Mammals of Ancient Egypt, Warminster (1998); J.Boessneck, Die Tierwelt des Alten Ägypten. München (1988).
} 
In the Egyptian folklore, putting a knife, loaf of bread and the Holy Quran under the baby's head (and placed a loaf of bread below the head of the deceased ${ }^{96}$. This identical to the ancient Egyptian thought: Evidence of putting a knife behind the head of the deceased from the pre-dynastic period. ${ }^{97}$ This practice developed to what we call "Magical Knife"98, from el-Lahun (Kahun) Berlin, SM 14207..$^{9}$ Five fingers amulet ${ }^{100}$ in Arabic: ( خمسة وخمبيسة khamsa wa khmisa): Fingers in religious texts refer to protection and ability; Pyr. 204, 292, 298, 465, 475 and 314. ${ }^{101}$

According to the Westcar papyrus to repeat the context of use of the birth bricks, after birth the child is placed on the bricks, with a cushion in between. ${ }^{102}$ ifd $m d b t^{103}$ which may perhaps be translated as an ifd-clothe, naturally the newborn bed especially for the poor people, they used a basket which is suitable by its shape for it. ${ }^{104}$ The box- beds were used for new infants, ${ }^{105}$

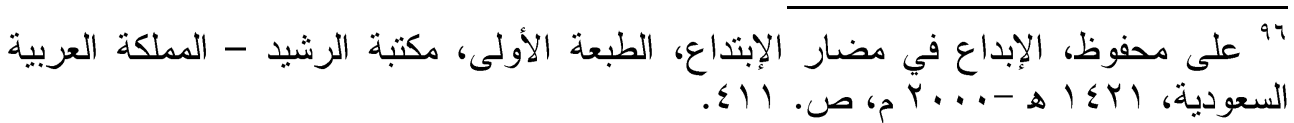

${ }^{97}$ Roth, JEA 78, 131-2.

98 JE 30032.

${ }^{99}$ Middle ringdom demons watched over the feeding of the child. An infant feeding -cup (New York, MMA 44.4.4) from el- Lisht is decorated with the same procession of a apotropaic figures (Bes- gods, Water turtle, lions, snake, a serpo-feline creature) as contemporary magic wands.

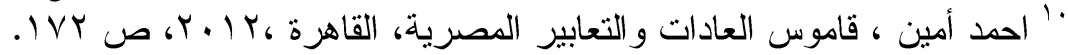

${ }^{101}$ For the hand, and two fingers as an amulets, it refers to the hands of Horus see: Bonnet, Realexikon, 637f; Bonnet Bilderatlas, 164; Andrews, Amulets of ancient Egypt, University of Texas Press (1994), p. 12; representations of a five fingers extended are found on buildings or tombs in Babylon, Phoenicia, Carthage, and India, E. Westermarck, Ritual and Belief in Morocco, vol. I., fig. 124.

${ }^{102}$ M. Lichtheim, Ancient Egyptian Literature, Vol.1, 1973, 215 ff. For the only actual birth brick to be recovered archaeologically see: J. Wegner,"Excavations at the Town of Enduring-are-the-Places-of-Khakaure-Maa-Kheru-in-Abydos: A Preliminary Report on the 1994 and 1997.Seasons", JARCE 35(1998) 3; id., "A Decorated Birth-Brick from South Abydos", in Egyptian Archaeology 20 (Spring, 2002) 3-4.

${ }_{103}$ Westcar 10, 2 ; $\underline{d b t} W b$. V, 553.

104 Basketry accessories: Footwear, bags and fans in ancient Egypt https://www.researchgate.net/publication/229416056_Basketry_accessories

Footwear_bags_and_fans_in_ancient_Egypt\#pfc [accessed May 5, 2016]. 
decorated with the figures of the god Bes. ${ }^{106}$ Troops of Bes gods occur in various other forms in bedrooms to bestow protection upon fertility, some lean on $s 3$-signs; some winged, carry $n b$ baskets with ${ }^{`} n \underline{h}, w 3 s$ and $s 3$ signs (Figure 4). It is necessary that the mother did not leave her baby alone or the place of birth for a week. This is consistent with public thought fear of it was altered by demons. ${ }^{107}$

\section{6- The Symbolism of number Seven:}

In Folklore this occasion was traditionally used for naming the newborn children, circumcising boys and piercing the ears of girl. As many ancient personal names refer to gods, they contain indirect information about the spread and the popularity of ancient cults. Names usually relate a newborn child to a specific god while also addressing the circumstances of birth. ${ }^{108}$ In $C T$ IV, 42i (Spell 291), it mentions that the deceased reborn as a child that he was made by his father and named by his mother. ${ }^{109} \mathrm{~A}$ possible reflection on Egyptian custom in naming new borns: ir n.s rn.f" for whom his name was made". ${ }^{110}$ In Egyptian folk in fellahin and Upper Egypt the parents frequently named the child

Cf. After Mary wrapped her New-born she put it in the place dedicated to an animal feed (مذود-Mazod), which is a basin carved in the rock (Eizekiel $\leqslant: 17)$.

105 B. Lesko, Houshold and Domestic Relugion in Household and Family Religion in Antiquity edited by Saul Olyan, J. Bodel, Blackwell Publishing 2008, pp. 197-209; E. Wente, Letters From Ancient Egypt, 1930, numbers 256, 280, 283.

106 Bes god has affinities with the procreation, assisted women after childbirth, during the mother's period of seclusion and purification. Rhis time was spent in a lightly built hut or "birth arbour" depicted on Deir el- Medina Ostraca; E. Brunner, Die Wochen laube, MIO 3 (1955), 11-30; id., Wochenlaube, LÄ VI (1986), 1282-4.

$$
\text { v• على محفوظ ، المرجع السابق، ص } 9 \text { • ؛. }
$$

In Morocco they belief that New-born infant, are in a great danger, there are jnûn wherever there is blood for forty days after birth a child must not be left alone, especially in the dark, lest some jnûn should come and exchange it; E. Westermarck ,op.cit.

108 J. Baines, Religion in Ancient Egypt: Gods, Myths, and Personal Practice, p. 178, note 153; Ranke, Personennamen, 3, pp. 30-81; G. Posener, sur L' attribution d' un nom a un enfant, RDE 22 (1970), pp. 204-5.

${ }^{109}$ The divine creator was called 'the one who creates the names' ( $\left.\mathrm{km} 3 \mathrm{rnw}\right)$; ibid;321.

110 See G. Posener, RdE 22 (1970), 204-205. 
by a poor name to drive evil away begging it to live. ${ }^{111}$ Catholics, Eastern, a Pray in the seventh day of the birth of the child practice by a priest in the child home by putting it in water. This prayer is called "Tsht" or "Hamim", ${ }^{112}$ Infant baptism is a practice of baptizing infants or young children ${ }^{113}$. The materials used in this prayer consistent of: Water: to be clean in everything, Oil: to be full of divine grace, Salt: to be of benefit and interest and the impact of, Candle: to be his luminous career and pure.

The number seven $s f h$ is linked to protection concept, perfection, effectiveness, completeness, a number of great significance in magic $^{114}$, and standing for a fortune number in general. Many instances cited by Seth from which it is clear that to do an action seven times was frequent in Egyptian magic. ${ }^{115}$ Seven gods in the form of small scorpions with Isis to protect her. ${ }^{116}$ The story takes up the majority of a Metternich stela recites how Horus was poisoned and cured. ${ }^{117}$ In the story of the 'Destruction of Humanity, ${ }^{118}$ in their human form, the Seven Hathors were

111

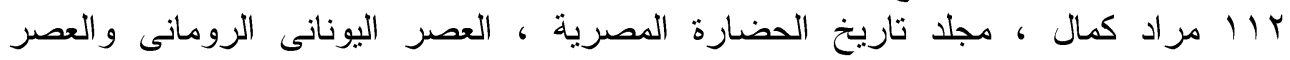

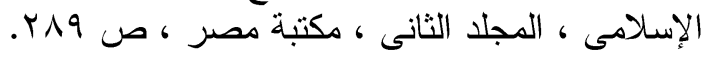
${ }^{113}$ Baptism is one the seven secret of the church its names: Second birth, New birth, Spiritual birth and it is a process of the death, burial;

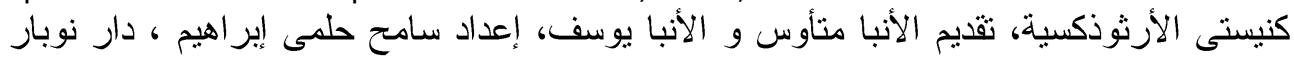

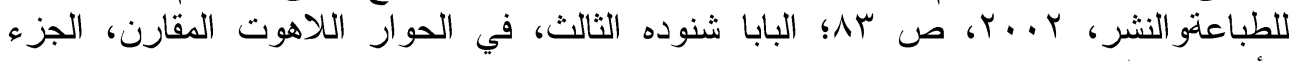

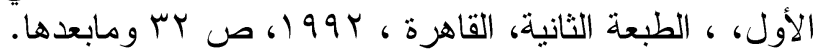
111 R. Wilkinson,"Meaning in Many: The Symbolism of Numbers," Symbol \& Magic in Egyptian Art, Thames and Hudson, 1994, pp.131-133; K. Highbaugh, The Esoteric Codex Numerology.

115 K. Sethe, Von Zahlen und Zahlwörten bei den alten Ägyptern, Schriften der Wissenschaftlichen Gesellschaft Strassburg 25, 1916, p. 33-37; F. Griffith, The Demotic Magical papyrus of London and Leiden, 1921, cols. XV, XVI, XVII, XIX, XX, XXI, XXVII, XXIX, XXXII.

${ }^{116}$ Meeks, F. Meeks, Daily Life of the Egyptian Gods, Cornell University Press (1996), pp. $82-86$.

${ }^{117}$ The majority of the stela relates how Horus was poisoned and cured see more in: Grajetzki, Wolfram. "Horus Stelae", University College London (2003).

${ }^{118}$ G. Pinch, Magic in ancient Egypt, British Museum Press (1994), p. 37. 
considered to be holy midwives (in't). They gave each Egyptian seven souls at birth and determined the fate of the newly born; The Seven Hathors are generally a positive force in magic. They are appealed to in love spells and their red hair-ribbons could be used to bind dangerous spirits. Representations of these seven forms of the goddess appear in the tomb of Queen Nefertari and in various versions of the Book of Coming Forth by Day. Spell $148 \mathrm{~b}$ consists of a vignette originally showing the seven cows and their bull. ${ }^{119}$ Hathor and Sekhmet both had a seven fold form. Seven knots BD 71. Very similar to the above text and again concerned with the seven knots of the celestial cattle it contains the following passage:

"O Seth, possessed of your power, Great Long horn dwelling in the northern sky when the Long horn is caused to ascend to the northern sky, see you have come under my feet; give to me air among the wtnw who give rest to the celestial cattle". ${ }^{120}$

The new Osiris remained without burial for seven days due to the tradition which declared that the god has remained for seven days in the womb of his mother Nut which was with child. During the seven day celebration of Apis birth, which was also conceived as the anniversary renewal of the world and the Nile, gifts were thrown into the river in order to bring about its rising.

CT 691= BD 71 The deceased calls upon the gods seven times with the words: Make me hale as you make yourself hale, release me, deliver me, (wh.k wi, sfh.k wi) and seven times the deity addressed answers Release him, deliver him, place him on earth grant his desire.

${ }^{119}$ Pp. 18, 33-36; http://www.touregypt.net/featurestories/mothers.htm\#ixzz47t6z1FKI

${ }^{120}$ R. Faulkner, The Ancient Egyptian Coffin Texts. Vol II, Warminster: Aris and Phillips (2004), p. 60.

${ }^{121}$ D. Bonneau, La crue du Nil, Paris , 1964, pp. 301, 398-401, 404-405; id., Les Fétes de la crue du Nil, RdÉ 24 (1972), p. 52. 
7-Festivals: The celebrations with the newborn of course are different than the religious ones. ${ }^{122}$ In the workmen's village at el-Amarna, there is a scene showing a procession of rejoicing girls and women. ${ }^{123}$ Two categories of feasts seen at Deir ElMedina: personal and general. The former is indicated by $p 3 y . f$ $h b$, the latter by $p 3 h b$. The first category was apparently observed by a single person (and his relatives/friends) and may indicate his birth-day.

Among the words for festivals: ' $n n$ hrw, hb, iry hrw nfr and prt $n$ $n \underline{t} r$ "processions". ${ }^{125}$ Dancing and singing takes place to welcome the newborn. Nubians have distinct songs and dances for the Seboua'ceremony. Although some Seboua' ceremonial songs are not totally comprehensible to many Egyptians, because of their ancient roots, the words are still repeated out of tradition. One song refers to the child's earrings.

In Seboua celebration "El-baiata" البياته Jug for a boy (Apreeq)

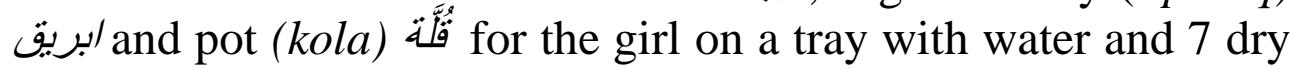
beans: rice and lentils, corn, wheat chickpeas ....(Seven seeds): the symbolic association between grain, fertility and rebirth ${ }^{126}$.

Seeds are an obvious analogy for rebirth, probably the clearest evidence to preliterate minds that seeds, which appeared to be dead when planted in the earth, would eventually germinate and comeback to life. ${ }^{127}$ They found around infant burials, this

${ }^{122}$ G. Mouron, Does $h b$ truly mean "festival" and were funerals one of them, in: The $67^{\text {th }}$ Annual Meeting of the American Research Centre in Egypt, p. 16.

123 B. Kemp, Wall Paintings from the workmen's village at el- Amarna, JEA 65 (1979), pp.47-53.

${ }^{124}$ R.Van Walsem, Month-names and Feasts at Deir el-Medinain: Gleanings from Deir ElMedina, edited by R. Demaree and J. Janssen, Leiden 1982, p. 223; S. Schott, Altägyptische Festdaten. Wiesbaden, (1950), p. 96, no. 1.

${ }^{125}$ See more different meaning in: D.Lorton, The Expression iri hrw nfr, JARCE 12 (1975), pp.22-31.

${ }^{126}$ Seven grains of barley see F. Griffith, op.cit, p. 105, col. XV.

127 The associations of burials with grain has a symbolic significance illustrated by the Ancient mythology, there was a prevalent belief that mechanisms of human reproduction paralleled that of plants, the term seed in still use right up to modern times. 
association could have developed the hope that a dead infant would come back to life like the grain and the protagonists of the myths.

Women were important as vessels that kept and protected the seed. A type of small pottery vial in the form of a seated woman holding up an infant child on her lap has been identified as a container for the milk of a woman which has given birth to a male child used in medical prescriptions and mentioned in magical spells against illnesses of women and child. ${ }^{128}$

the vessel \& W9 has a slight necks, without prominent lip; ${ }^{129}$ $h n i^{130}, \underline{h} n m,^{131}$ related to Khnum the major creator-god in the Egyptian tradition. Swelling of the vessel represents the mother's bulging abdomen. Many pots suggest this symbolism. ${ }^{132}$

In the Neolithic period; Jar-burials are a repeated pattern in archaeological sites, cooking jars were used for the burial of infants and small children, ${ }^{133}$ The head of the child was placed in a downward position, which is the correct presentation for fetus to be born or in its re-born by placing of the dead in a clay 'womb' to facilitate a new birth.

128 Metropolitan Museum 25.7. 42; Desroches- Nonlecourt, Pots anthropomorphes et recettes magicomédicales dans l' Egypte ancienne, Reve d' Égyptologie IX, (1952), p. 59.

${ }^{129}$ Like prominent handles on the tipped -over pots on the Tutankhamun shrine read more:

P. Kaplony, Wasser, in LdÄ, vol. 7, col.32.

${ }^{130}$ hni ver see $W B$ III 374, 77.

${ }^{131}$ Wb. I. 207; III, 377, 382.

132 18. Dyn, JE 34403.

${ }^{133}$ Children are buried in settlements sometimes in pots at Badari and Ballas; Brunton, G. I Caton-Thompson, G., The Badarian civilization and Predynastic remains near Badari [British School of Archaeology in Egypt Publications 46], Londres (1928); W. Petrie / Quibell J.E. / Spurrel F.C.J., Naqada and Ballas: 1895 [Egyptian Research Account Memoir 5], Londres (1896); cf. P. Mcgeorge, Intramural infant burials in the Aegean Bronze age, HAL archives- ouvcrtes (2013). European prehistoric pot burials see: K. Bacvarov, Where do children belong? Neolithic burials in western Bulgaria (2005), pp. 149-56. 
Peasants placed seven seeds next to the baby until the seventh day of his birth, which prevents its harm from metaphysical creatures that surround it. The existence of such grain carries a degree of comfort demons. Onion was applied to the eye of the newborn in the Seboua. Onion is used as a food and for medicinal application in the treatment and prevention of a number of diseases. ${ }^{134}$

Seboua Folklore's Rituals in Order: Scattering Salt, burning incense - Sieving ritual (winnowing- the mother steping over the new-born 7 times), Ringing the Huns (copper pestle), Circl around with candles, The roaming mother with the newborn around the house.

The Seboua events start by scattering salt on the mother and around the house to keep away the evil eye. The hieroglyphs "ntry" most likely derived from the root "ntr", indicates its association with religious and funerary rituals. The tradition of throwing salt is meant to ward off evil, presumably by making spirits unable to see from the salt in their eyes. The woman in Seboua burns incense; a certain types of incense were used for specific ceremonies. Burned incense due to favor the gods and enrich their own environment. The root $i d i$ is used of censing in the pyramid Texts ( $W b$ I 152, 5-11) and of quenching a fire in the coffin Texts (CT VII 96j-m, 275a).

At the beginning of the celebration, the baby is placed in a sieve (ghorbal) غربال, a kind of tray with a bottom net. ${ }^{135}$ Primary winnowing is done to separate the threshed cereal spikelet from the remaining straw used in the process of winnowing, ${ }^{136}$ actually

134 V. Lanzotti, The analysis of onion and garlic, Journal of Chromatography A, Volume 1112, Issues 1-2, 21 (April 2006), Pages 3-22.

${ }^{135}$ Ian Shaw, P. Nicolson (eds.) Basketry, Ancient Egyptian Material and Technology, p. 265.

For the grid of sieves both the active and passive elements of the twin grid were evenly spaced. The size of the strands and the space between them varies with the function of the sieve.

${ }^{136}$ Ian Shaw, op.cit, p. 525. 
in practice during the early Egyptian era as grains were sized with 'sieves' of woven reeds and grass. ${ }^{137}$ In Old Kingdom unlike later periods, the winnowing and sieving of grain was always performed by women, perhaps in teams of five, for they are called diwt "fivers ${ }^{138}$. Sieve was used in the rites of several religions; Isis emerging from large basket. ${ }^{139}$ Osiris rising up out of a basket which rests upon a pedestal, ${ }^{140}$ served also as a basket

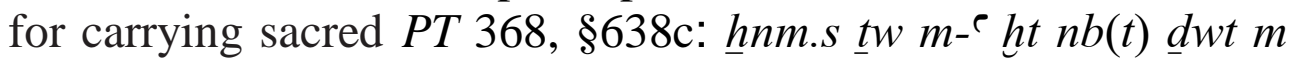
rn.s $n$ hnmt wrt "She will shield you from everything bad in her identity of great sieve": nhm.s tw $m \mathrm{-}^{\mathrm{c}}$ ht $n b t \underline{d w}(t) m$ rn.s $n \underline{h n m t}$ $w_{r t} t^{141}$ "She will save you from everything bad in her identity of Great Sieve, "mfh" sieve (grain)" (from the root $f h$ "shed"). ${ }^{142}$ The child usually slept through the vibration and movement associated with the sieve are the same; The Ancient Egyptian sieve hieroglyph is Gardiner sign listed no. is Aa1 for the shape of a circular sieve; it is also seen as a 'placenta'. ${ }^{143}$ This sieve is also connected to the basket, bilateral for nb, ${ }^{144}$ no.V30 for a semicircular-shaped, shallow basket wicker basket $k b 3 t$ $\mathrm{KaBai}^{145}$ basket for everything, every, major use, lord, used

137 D. Samuel, 'Brewing and baking', in P. T. Nicholson and I. Shaw (ed.), Ancient Egyptian materials and technology, Cambridge: Cambridge University Press (2000), pp. 537-76; Samuel, Experimental grinding and Ancient Egyptian flour production. in S. Ikram \& A. Dodson (eds), Beyond the Horizon: Studies in Egyptian Art, Archaeology and History in Honour of Barry J. Kemp. Cairo: American University in Cairo Press (2010), pp. 456477.

138 G. Fischer, op.cit, p. 22.

${ }^{139} \mathrm{Cf}$. Plutarch, de. Is. Et Os.35, 365A, has a vivid allusion to the secret sacrifice offered in the temple of Apollo in Delphi when the god of the secret basket (Likinites) was awakened; Griffiths (ed.), The Isis - book, Leiden, 1975.

140 Budg, op.cit, p. 138.

141 Ibid, 178:33.

${ }^{142}$ T. Shmakov, Critical analysis of J. Allen's, The Ancient Egyptian Pyramid Texts (2012), p. 189; Allen, 189.

${ }^{143}$ M. Collier, and B. Manley, How to Read Egyptian Hieroglyphs, 1998, University of California Press, p.179.

${ }^{144}$ Wb II, 234.3-236.5; Wilkinson, Reading Egyptian Art: A Hieroglyphic Guide to Ancient Egyptian Painting and Sculpture, 1992, pp. 198-199.

145 A. Alcock, Coptic for Containers and Measures, Zeitschrift für Demotistik und Koptologie 23, 1996, p. 2. 
with the meaning of heap, load basket in religious texts (Pyr. 76, $152,158,159,160,161,162,167,166,168)$ usually connected fruits, bread, gods, eye of Horus and protection. Pyr. 638 "The mother Nut is spread over thee..... she causes you to be a god... she protects you from all evil in her name, she of the Great sieve you are the eldest of her children". ${ }^{146}$ Isis also emerging from a large basket, Osiris has been found in the khoiak rites at Denderh related to the basket of rushes called insw or inswty ${ }^{147}$

Allen, spell 178s1: "O Goimg forth by day (they mother) Nut spread herself over thee in her name of (goddess of) the Wadi Natrun oasis. She makes thee a follower of the great god, without enemies. She (protects) thee from everything evil in her name of Great Sieve (hmt-wrt). You are the eldest of her children". From the other hand, Blackman's ethnography of the peasants of Upper Egypt depicts this equipment, a birthing stool and a woman leaning up on a sieve while sitting on the stool. ${ }^{148}$ Stepping over the sieve as she carries her newborn, taking seven steps is an ancient Egyptian tradition intended to ward off the evil eye and then walks, in folk women and the grandmother repeats the commands to the infant, telling him to obey his mother and not his father, in a funny rhyme.

Winnowing: After threshing, the kernels were gathered by the process of winnowing at the threshing floor. The focus on grain and burial can have been be found already in the Middle Kingdom with earth packets and gridded sowing beds in funerary contexts such as the pyramid complex of Senusret II at Lahun, and formulae among the funerary literature such as Coffin Text 269 'formula to become barley', in which the deceased becomes 'the life that comes from Osiris', and Coffin Text 330 'formula to become Nepri' (personification of grain). Similarly,

146 The child Dionysus was awakened in a winnowing basket.

147 Wb I, 100, 17; Chassinat, Le Mystere d' Osiris, p. 65.

${ }^{148}$ W. Blackman, The Fellahin of Upper Egypt, London (1968), figs 28, 29. 
shaking the sieve is meant to teach the infant that life could place them in changeable situations, ${ }^{149}$ so the sieve represent a baby and is itself a fertility.

One of the most important popular steps nowadays is the ranging of the copper vase with its handle (Dek el-Hun) the Arabic word may be related to the ancient word $h n, h n w$ Ð Jar, vase, pot, copt hin- Huns- symbolic. The banging of the pestle and mortar probably started as a small deep in a rock. Small mortars have been commonly found in the domestic housing at workmen's villages excavated at Deir el-Medina and Amarna. People have used mortars for many centuries to grind or mix grinds. The Ebers Papyrus listing remedies for many diseases mentions a mortar. It is believed that hearing starts seven days after birth. During this ceremony, the mother the steps over the baby seven times without touching it, while older women make loud noises to make the baby aware of sounds. Grandparents shake the baby horizontally and give him orders to obey only their family.

The Symbolic Functions of the banging mortars:

1- In ancient Egypt, the ritual was connected to agricultural life. Mortars are used for cracking grain by pounding with a pestle. cf. CT IV, 13e-14a: thny 3sir(t) $N$ pn m bjk ntrr r-s3 wgw. $f$ "This Osiris $\mathrm{N}$ has alight as a divine falcon behind his $\log ($ ?)", smn "beat dough" on smin "introduce" $(\S \S 1418 b, 1420 b$, \{pestle and mortar\} The spelling of the verb smin also involves the secondary determinative \{pestle and mortar\} as influence from the verb smn, probably "beat dough". ${ }^{150}$

2-In Folklore intended to get the infant used to the noise and disturbances of life.

\footnotetext{
${ }^{149}$ The blessing by the means of using the winnowing tray was carried out in other cultures; B. Maurice, From Blessing to violence, Cambridge (1996), p. 150, no.9.

${ }^{150}$ smnt "prüfen", "das Brot prüfen"; Hannig, $\ddot{A} R$, p. 1126 " follows Junker, Giza XI, Abb. 64, p. 162.
} 
Circling as a cult ritual was due to ancient Egypt. Egyptians realized that the rotation is the basic principle of the universe, spiritual joy, eternal symbol, symbol of eternity and continuity.151 Protection described as being "around something. ${ }^{152}$ The word $p \underline{h} r, p h r r^{153}$ wnwn, and $h k s{ }^{s} n l^{154}$ are important in the magical vocabulary of ancient Egypt, where encirclement and protection are closely associated, by traveling about; the sun god encompasses, rules, and protects the cosmos. In Graco - Roman period; Plutarch writes that at the time of winter sostic they lead the cow seven times around the temple of the sun; because the sun completes its passage from winter to summer solstice in the seventh month. ${ }^{155}$ The symbol ritual of kindling of the candles at childbirth ${ }^{156}$, symbolizes life, and celebration. It is also commonly used as part of religious ceremonies and holidays, and in each instance, the meaning may differ reliant on the traditional beliefs. In ancient Egypt the light related to the sun god defeated the powers of chaos.

Ritual and recitation indeed was capable of to producing more effectiveness so during this circulation in folklore, they chanted a song which is still unclear in meaning, but some words are related to earrings (Hours); in ancient times earrings were predominantly male ornaments. Egyptians and Assyrians used earrings to signify the fact that they belong to a higher class. At the end of the Sebuoa, the roaming of the mother with her child (Figure 6); expresses the roaming of Isis in the Delta attempting to protect Hours (stela Louvre C 286). The mothers act here simulates that of goddess Isis: the inscription reads: "Isis who

151 Cf. Sufi rotation, Alrohban rotation with the Baptized three times, carrying candles in church.

${ }^{152}$ Cf. A. Klasens, A Magical Statue Base in the Museum of Antiquities at Leiden, Leiden (1952), p. 81.

${ }^{153} \mathrm{~Wb}$ I, 541, 2-13.

${ }^{154}$ C. Darnell, The Enigmatic Netherworld Books of the Solar- Osirian Unity, note 201.

155 J. Griffiths, Plutarch, pp. 201-203.

156 H. Brunner, Die Geburt des Gottkönigs, Wiesbaden, 1964, 104-105; cf. Pap. Ram. IV, C 12-13. 
resides in Nekhen Mistress of Good Fat ....He (Hours) is healthy on her arm". ${ }^{157}$ A tale about Isis wandering through the Delta in flight from her brother Seth and in the company of seven helpful scorpions was used as a mythical antecedent in a magical spell to cure the scorpion bites. ${ }^{15}$

8- Conclusion: Local festivals in ancient Egypt incorporated rituals and ceremonies as an integral part of the pregnancy and birth experiences which tend to appear less often, perhaps owing to their circumscribed and often exclusively rural functions, The learned patterns of thinking, feeling and acting are transmitted from one generation to another to compose a special social heritage. Welcoming a New Born Baby in Egypt depict similar patterns of celebration. ${ }^{159}$ These ritual practices are likewise observed by both Muslims and Christians, though with differences. Seboua dates back to the ancient Egyptians, confirmed by that most of these rituals have no meaning in the monotheistic religions which confirms being a cultural heritage. For Christians, it has been linked to some of the intimate rituals such as "Hamim" prayers and baptism and here related to Jesus Christ. For Muslims, Islamic words are added to cope with Islam, traditional songs with a sense of humor ${ }^{160}$. These traditions got gradually replaced by preparing a feast and cooking the Aqiqah (the slaughtered sheep or lamb).

Despite the absence of full consecutive rituals from Ancient Egypt, however these manifestations are undoubtedly taken from

157 E. Walters, Fate, Gaiety and Women in the cult of the Egyptian Goddess Isis at Hierakonpolis Tomb of Hormose, (Twenty First Dynasty) Abstract for the Archaeological Institute of America annual meeting, Chicago, December 28 (1997), AJA (1998), vol. 102, p. 387, Fig. 3.

${ }^{158}$ E. Wente, Late Ramesside Letters, in: Textes et langages de l'Egypte pharaonique. Cent cinquante annees de recherché (1822-1972). Hommage a Jean-Franyois, Champollion II, Le Care (1973), 103-106.

${ }^{159}$ F. Heba, The Sebou Ceremony Welcoming a New Born Baby in Egypt. Read more http://www.touregypt.net/featurestories/sebou.htm\#ixzz46qv4g9s.

${ }^{160}$ The women and the grandmother repeat commands to the infant, telling him to obey his mother and not his father, in a humorous fashion. 
ancient Egypt, separate images associated with the newborn are connected with the folklore, such as the birth of Horus the child and the rebirth of Osiris. Finally these manifestations in all cases reflect happiness with the newborn. 


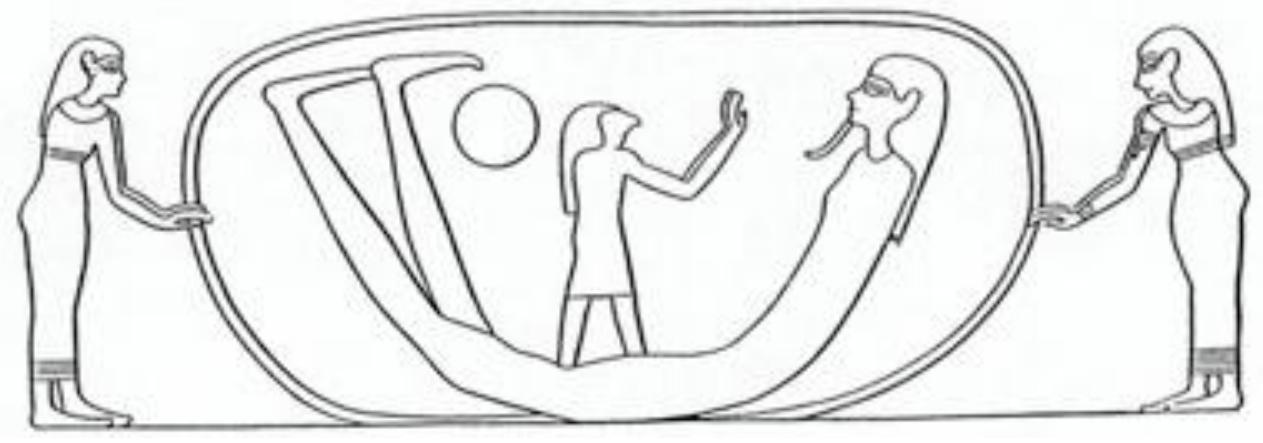

Figure 1-The Drop of Semen in the Womb

The bent body of the father Osiris lies in the drop of semen Stricker, Birth II, Fig. 16: 90.

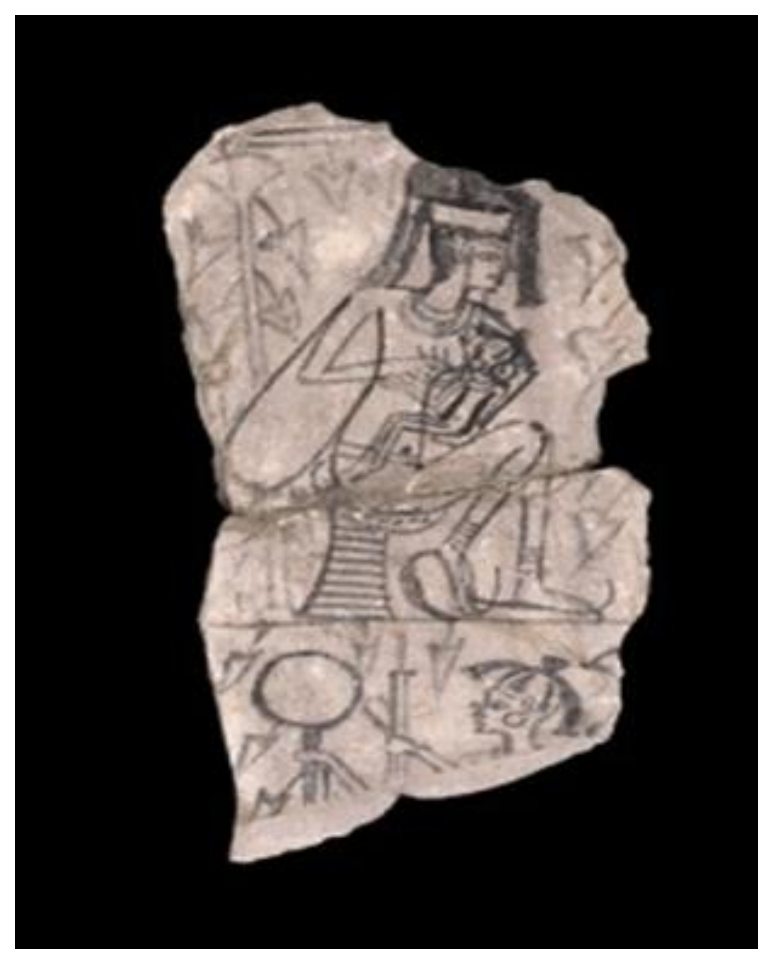

Figure 2- Mother and child in a birth arbour-ostracon

From Deir el-Medina-19 $9^{\text {th }}-20^{\text {th }}$ Dynasty British Museum- EA 8506 


\section{Studies on the Arab World monuments 18}

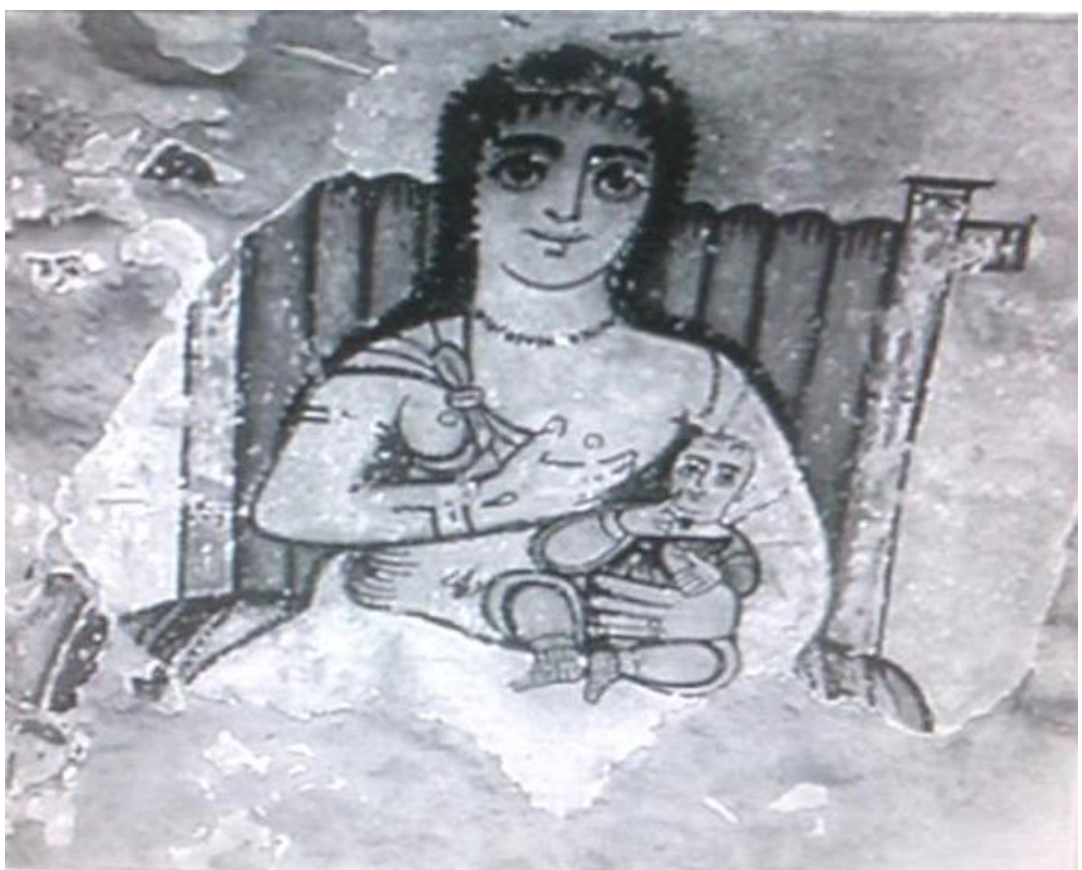

Figure 3- Water colour of mural of Isis, from a domestic structure at Karanis House B 50

Kelsey Museum of Archaeology, KM 2003.2.2.

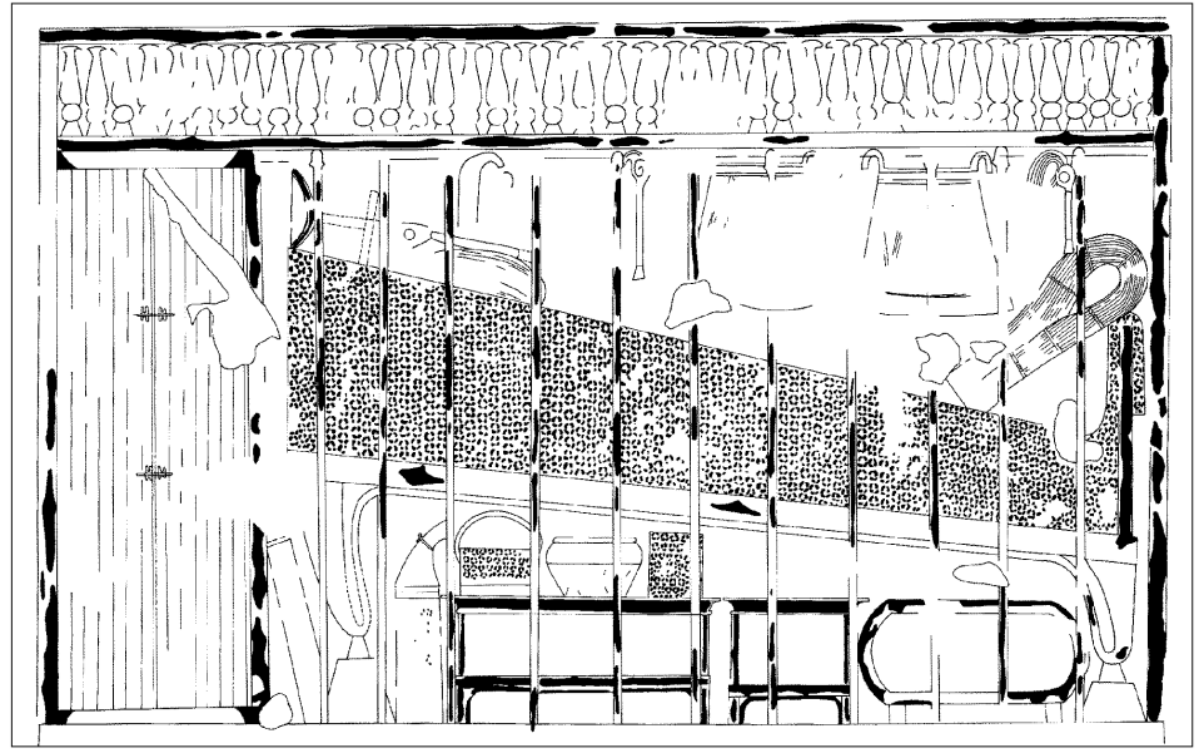

Figure 4-Decoration on the bed of child

A. Moussa, F. Junge, Two Tombs of Craftsmen AV 9, Meinz, 1975, pl.1. 


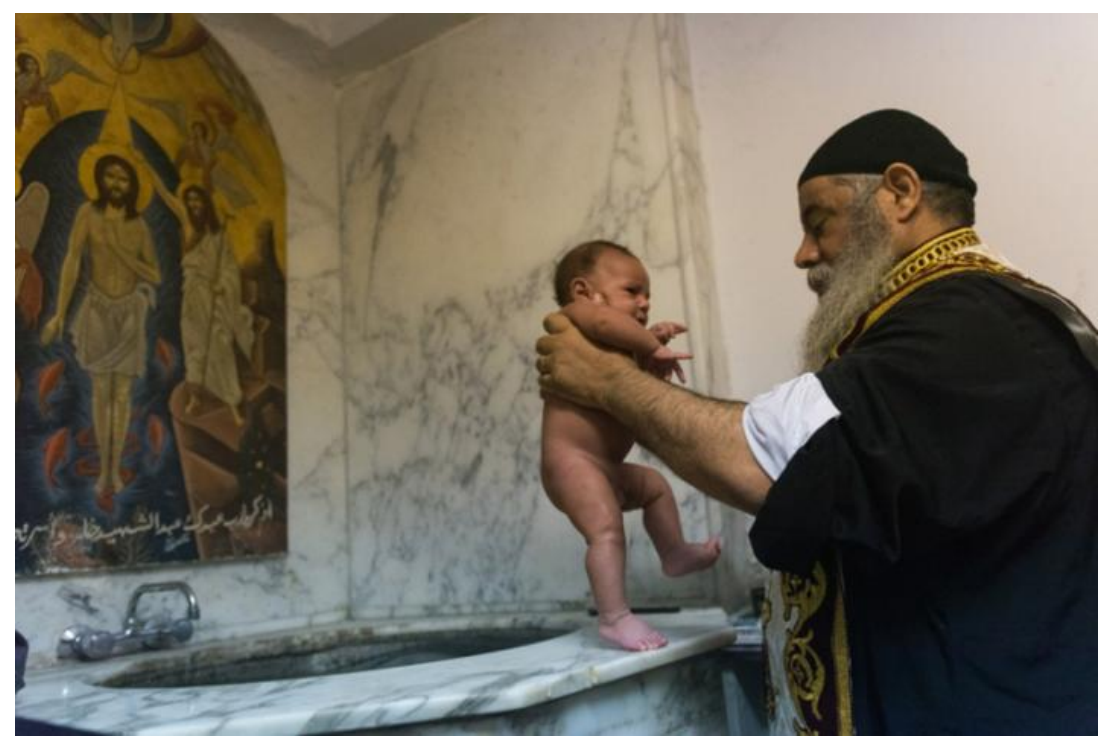

Figure 5- Baptism

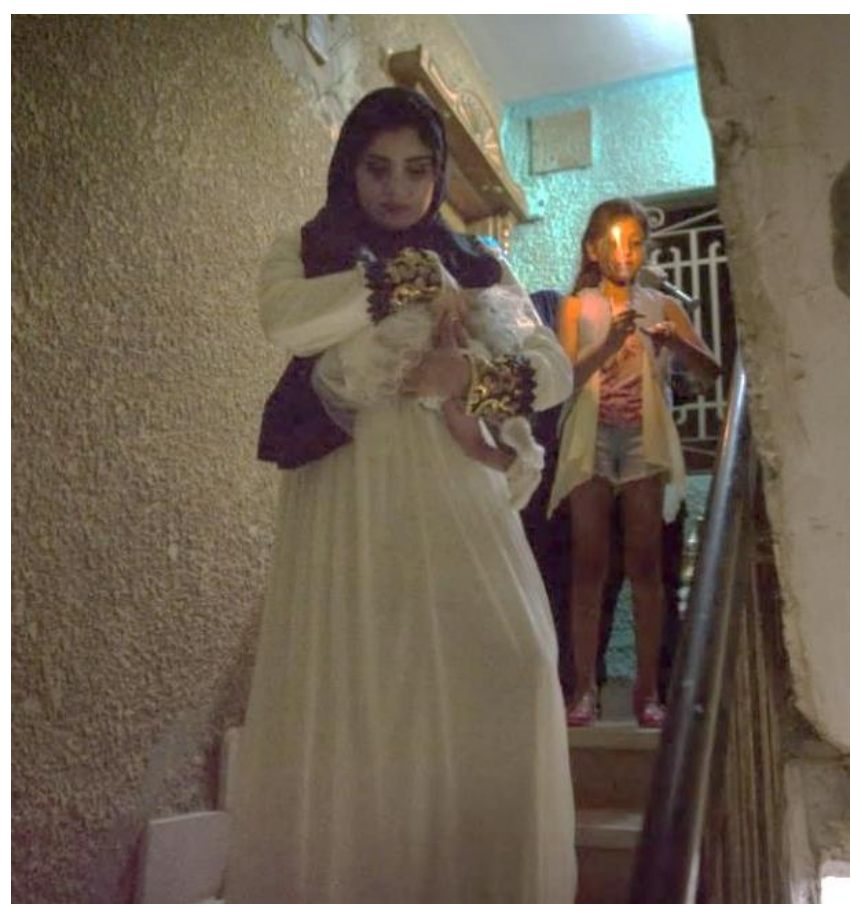

Figure 6-The mother holding the newborn walks down the stairs with the rhythm of the banging pestle and mortar

Behind her, children carry candles to light her path. 


\section{مظاهر الفرح بالمولود في مصر القديمة وصلتها بالموروث الثعبى}

\section{د/ نور جلال عبد الحميد}

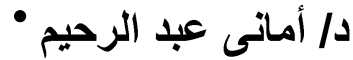

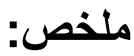

يختص هذا البحث بدر اسة مظاهر الأهتمام والفرح التى تدورحول المولود في مصر القديمة ورصد ما تبقى من تلك المظاهر أو الطقوس في موروثنت الثنا الشعبية وترجع أهمية هذا الموضوع لكونه مرتبط بهدف مهر في في حياة المصريين

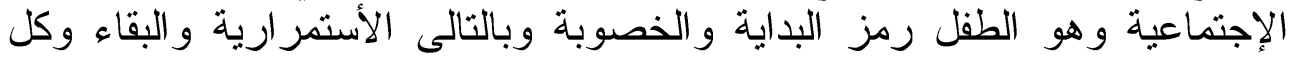

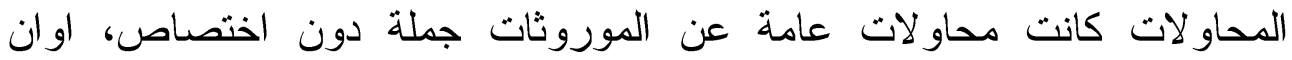

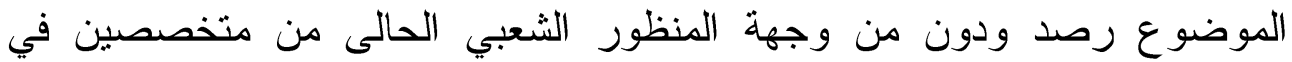

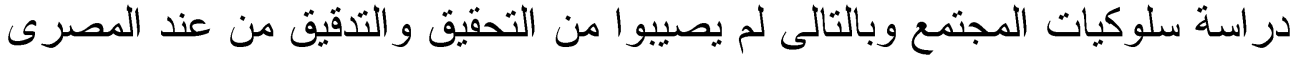

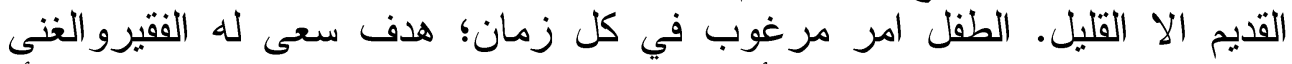

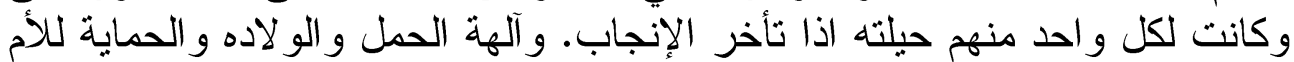

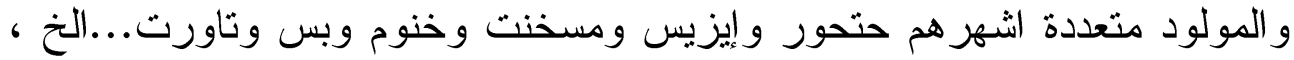

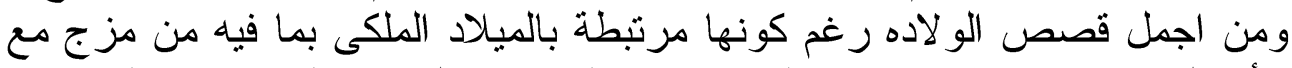

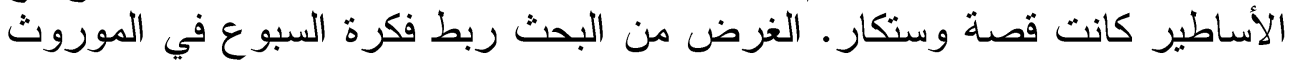

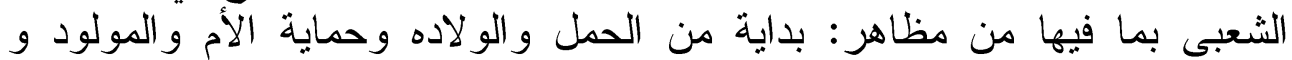

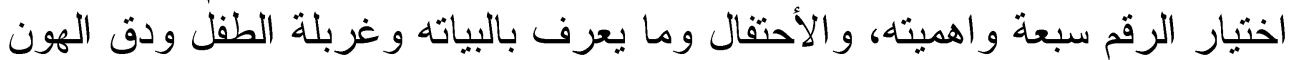

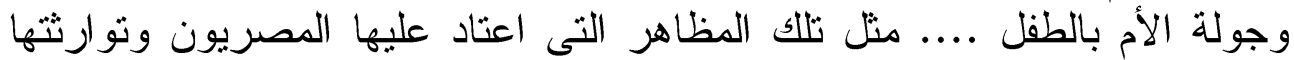

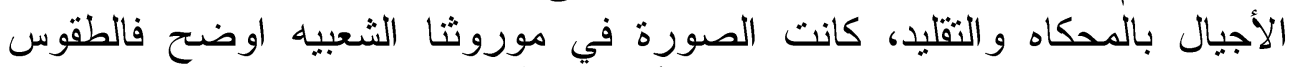

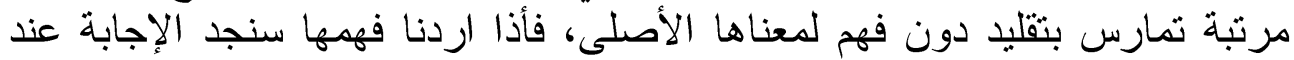

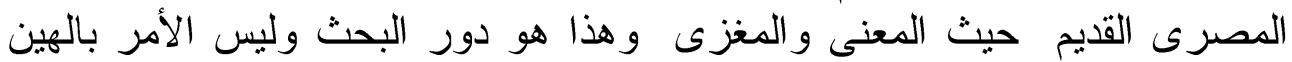

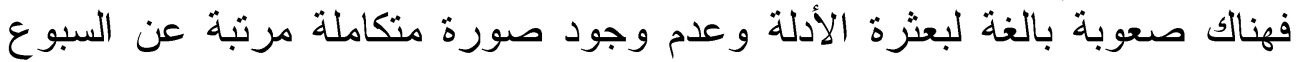

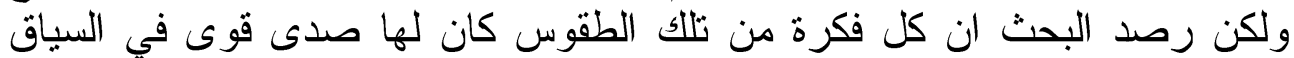

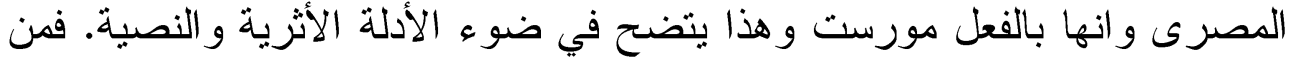

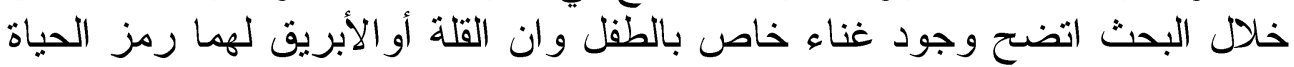

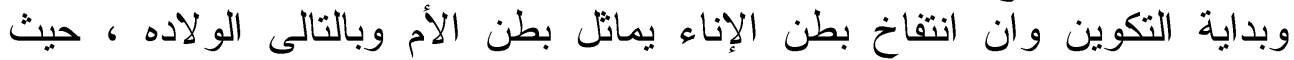

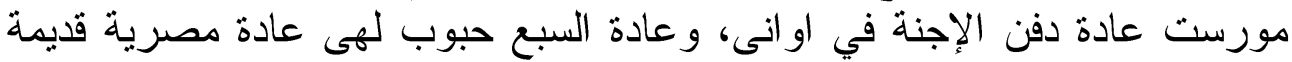

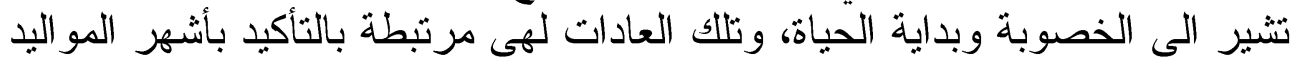

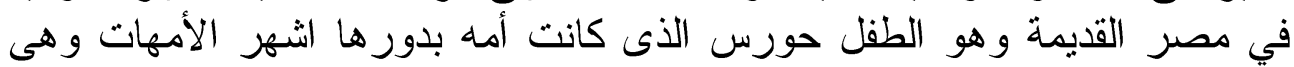


ايزيس فحركة الأم بالمولود في السبوع تمثل فوز الأم أيزيس بالمولود ومحاولة حمايته من الأخطار المحدقه باله.

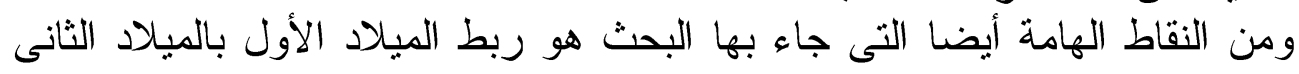

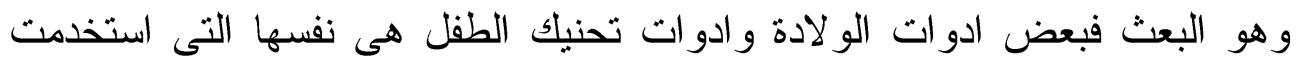

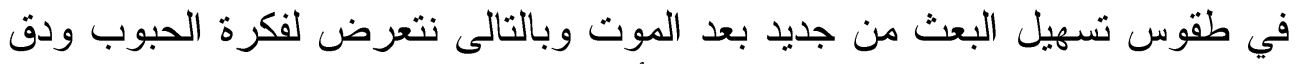

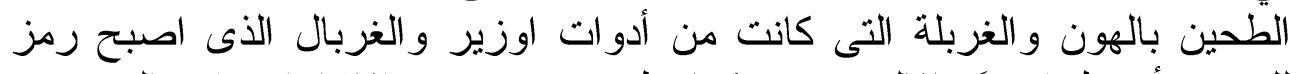

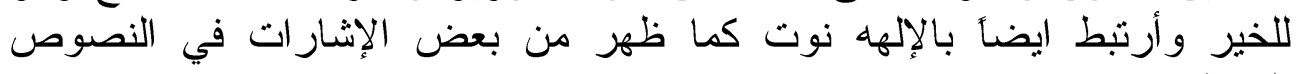

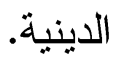

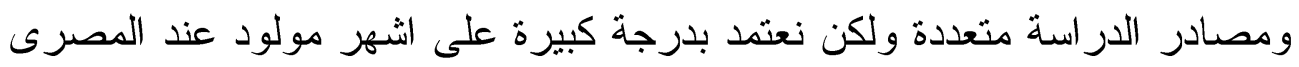

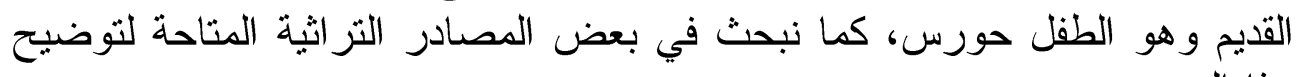

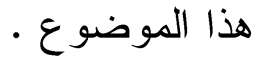

